\title{
オープンプラン教室配置における音響伝搬特性の検討 STUDY ON REDUCTION OF SOUND PROPAGATION BETWEEN OPEN-TYPE CLASSROOMS
}

\author{
中 島 章 博*1, 上野佳奈子*2，坂 本 慎 一 $* 3$, 橘＼cjkstart秀 樹*4 \\ Akihiro NAKAJIMA, Kanako UENO, Shinichi SAKAMOTO \\ and Hideki TACHIBANA
}

\begin{abstract}
In Japan, "open-plan" type classroom is becoming popular in elementary schools. Although this planning has various merits for educational activities, sound propagation between adjacent classrooms tends to be a serious acoustical problem. In this study, therefore, the sound propagation between closely located two classrooms connected by an open-space was investigated by numerical simulation using FDTD method. In the simulation, two classrooms and the open-space connecting them were modeled and the configuration of the rooms and sound absorption treatment on the room boundaries were examined. As a result, it has been found that sound absorption treatment on the ceiling and architectural/acoustic treatment for the wall of the open-space which makes mirror-reflection are effective to mitigate the sound propagation between the classrooms.
\end{abstract}

Keywords : Classroom acoustics, Open-plan classrooms, Sound propagation property, Numerical analysis, FDTD method 学校音響, オープンプラン教室, 音響伝搬特性, 数值解析, FDTD 法

\section{1. まえがき}

近年、わが国の小学校では、明治以来学校建築の定型となってき た片廊下型平面に代わって、オープンプラン(以下 OP)教室配置が採 用されるケースが増えている ${ }^{1), 2)}$ 。 OP 教室は、空間の連続性や開放 性が特徴で、チームティーチングや学年一斉授業などさまざまな学 習形態に対応した活動を展開寸ることができる。その一方で、教室 どうしが壁を隔てずオープンスペース(以下 OS)を介して空間的に つながっているために教室間の遮音性能が低く、隣接教室からの伝

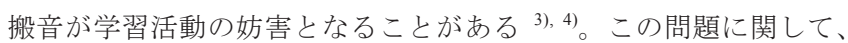
青木ら ${ }^{3)}$ や井上ら ${ }^{5}$ は、OP 小学校における運用状況の調查を行って おり、OP 教室を効果的に活用するためには隣接教室を考慮した時 間割を組むなど、OP 教室配置にふさわしい運用を行うことによっ て音の問題を回避するという運用面での工夫が重要であること、そ れと同時に、教室間の伝搬音を低減するための音響設計の重要性を 指摘している。

学校施設の音環境については、日本建築学会からいわゆるアカデ ミックスタンダードとして「学校施設の音環境保全規準」 ${ }^{6}$ の発行 が予定されており、普通教室間の遮音性能としては D-30 が推奨値 として示されている。しかし、OP 教室でこの遮音性能を満足する ことはほぼ不可能であり、OP 小学校にそのまま適用することはで きない。OP 教室の音響特性に関しては、青木ら ${ }^{3)}$ 、井上ら ${ }^{7)}$ 、福山 $ら^{8)}$ 、中島ら ${ }^{9}$ が実測や模型を用いた教室間遮音性能の検討を行っ
ている。これらの測定および実験から、隣接教室からの伝搬音は音 響的対策をとっていない教室では非常に大きく、また教室配置や天 井および壁面の吸音処理により音の伝搬のしかたに差があることが 示されている。したがって、教室配置の工夫や適切な吸音処理を行 うことが重要であり、そのためには、実際の設計に応用可能な設計 法や有効な対策について、建築的手法と音響性能の関係を定量的に 示す設計資料の整備が必要である。

筆者らは、室内音場での音響過渡現象を把握するうえで優れた数 值解析手法である FDTD 法(時間領域有限差分法) ${ }^{10)}$ を教室空間の解 析に応用し、さまざまな条件で教室間の音の伝搬特性を解析するこ とによって建築的要素と伝搬音の低減との関係を把握し、音響設計 に役立つ知見を探ってきた ${ }^{11)}-13$ 。 まとめて報告する。その内容としては、まず、この数值解析手法の 有効性を確認するため、実測結果と数值解析による結果を比較した。 つぎに、隣接教室に伝搬する音の経路に着目し、代表的な教室配置 や内装仕上げ等の音響設計要素の各種条件について検討を行った。 また、実際の運用時には家具類が設置されることも考慮し、その影 響について数值解析および実測調查による検討を行った。

\section{2. 検討方法}

\section{1 数值解析手法の概要}

音響における FDTD 法 ${ }^{10)}$ では、音波の挙動を記述する時間領域の
*1 東京大学大学院工学系研究科建築学専攻 大学院生

*2 東京大学生産技術研究所 助教・博士 (工学)

*3 東京大学生産技術研究所 准教授・博士 (工学)

$* 4$ 千葉工業大学 教授·工博
Graduate Student, Dept. of Architecture, Graduate School of Eng., Univ. of Tokyo Research Assoc., Institute of Industrial Science, Univ. of Tokyo, Dr. Eng. Assoc. Prof., Institute of Industrial Science, Univ. of Tokyo, Dr. Eng.

Prof., Chiba Institute of Technology, Dr. Eng. 


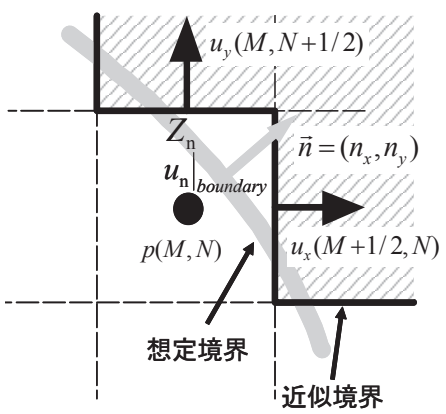

図 1 境界面の近似表現

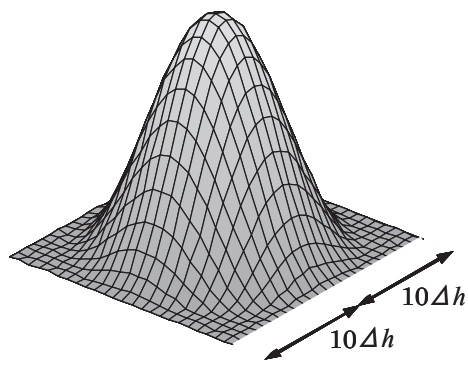

図 2 インパルス音源の形状

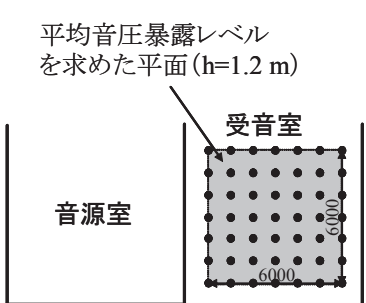

図 4 平均音圧暴露レベル算出に用いた受音点
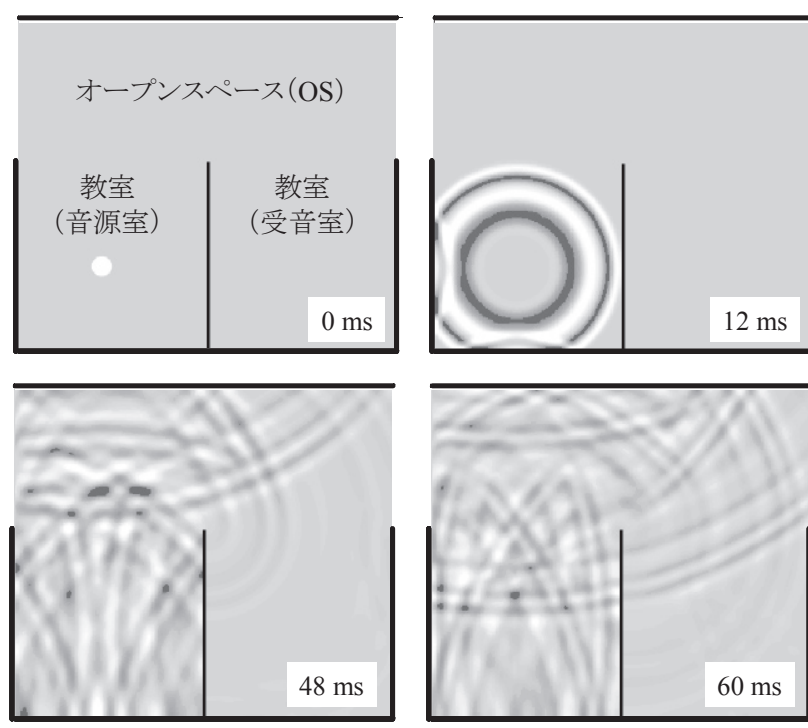
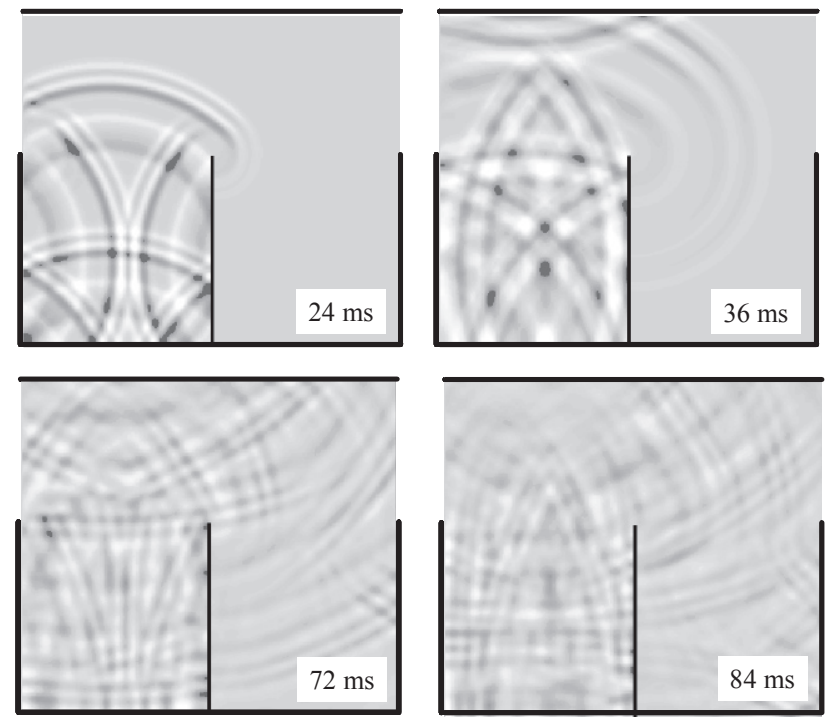

境界面吸音率 0.1

図 3 高さ $1.2 \mathrm{~m}$ の平面におけるインパルス音の伝搬の様子（図中の時刻はインパルス音源放射後の経過時間）

微分方程式であるオイラーの方程式と連続の式の空間および時間に 関する微分項を差分近似して解くことにより、音響伝搬過程の各時 刻における音圧と粒子速度を求めることができる。本報では、この 数值解析手法を 3 次元空間に適用し、直交格子で対象音場を離散化 した。室の境界面形状が直交格子に一致しない場合には、図 1 に示 すように境界面を折れ線近似する方法を適用した。空間格子の寸法 は対象とする音波の波長に対して $1 / 10$ 程度の大きさに十分小さく する必要があり、本研究では中心周波数 $500 \mathrm{~Hz}$ のオクターブバンド までを計算対象としているので、その上限周波数 $707 \mathrm{~Hz}$ の波長が $0.48 \mathrm{~m}$ であることを考慮して空間離散化幅を $0.05 \mathrm{~m}$ とした。また、 時間離散化幅は $0.08 \mathrm{~ms}$ とした。

境界条件については、次式で表される局所作用性を仮定し、室内 表面の部位ごとに所定の音響インピーダンスを設定した。

$$
\left.u_{n}\right|_{\text {boundary }}=\frac{p}{Z_{n}}
$$

ここで $\left.u_{\mathrm{n}}\right|_{\text {boundary }}$ は、境界上における垂直方向の粒子速度、 $p$ は音 圧、 $Z_{\mathrm{n}}$ は境界上法線方向音響インピーダンスである。なお、本研究 における解析では、境界上の音響インピーダンスについて実数項の みで近似することとし、部位ごとに設定した吸音率から次式によっ て音響インピーダンスを計算した。

$Z_{n}=\rho c \frac{1+\sqrt{1-\alpha_{n}}}{1-\sqrt{1-\alpha_{n}}}$
ただし、 $\alpha_{n}$ は垂直入射吸音率。

初期条件としては、インパルス音源として所定の音源点に次式で 表される余弦波形状をもつなめらかな音圧分布(図 2)を与えた。

$p(r)= \begin{cases}1+\cos \pi \frac{r}{10 \Delta h} & (r<10 \Delta h) \\ 0 & (r>10 \Delta h)\end{cases}$

ここで、 $r$ は音源点からの距離、 $\Delta h$ は空間離散化幅であり、今回 の解析では $\Delta h=0.05 \mathrm{~m}$ としている。上記の条件による音源がもつス ペクトル特性は、約 $1.2 \mathrm{kHz}$ で最初のディップが生じる周波数特性 となっているが、 $500 \mathrm{~Hz}$ のオクターブバンドの周波数帯域で十分な エネルギーを有している。

\section{2 解析結果の表示方法}

以上の方法で求められた 3 次元の解析結果を可視化するために、 対象とする空間の床上 $1.2 \mathrm{~m}$ の平面内の受音点におけるインパルス 応答を出力し、その平面上における音の伝搬の様子および音圧暴露 レベルの分布を以下のように表現した。

1) 過渡応答アニメーション

$0.05 \mathrm{~m}$ の空間グリッドにおける音圧を $0.8 \mathrm{~ms}$ ごとに色の濃淡で表 現し、アニメーションとして可視化した。標準的な OP 教室配置を モデルとし、音源から放射されたインパルス音の音波伝搬過程をス ナップショットで表した例を図 3 に示す。これをアニメーションで 観察すると、時間経過に伴う音波の伝搬、反射や回折などの様子が 
視覚的に確認できるため、この方法によって各建築部位の寄与が直 感的・客観的に把握できる。図 3 中、インパルス音の放射後 $24 \mathrm{~ms}$ の時点では回折音が隣接教室に入射し、36 ms の時点では OS 壁面で 音波が反射し、60 ms の時点ではその音波が隣接教室に入射する様 子が見られる。

2) 音圧暴露レベルの空間分布

床上 $1.2 \mathrm{~m}$ の平面内で $0.5 \mathrm{~m}$ グリッドの格子点ごとに中心周波数 $500 \mathrm{~Hz}$ の 1 オクターブバンドのインパルス応答の 2 乗積分值を求め ることによって音圧暴露レベル $\left(\right.$ 以下 $L_{p \mathrm{E}}$ )を算出し、その分布を色の 濃淡で図示した (図 8,16)。

3) 受音側室内における平均音圧暴露レベル

受音側室内の壁から $0.5 \mathrm{~m}$ 以上離れた $6.0 \mathrm{~m} \times 6.0 \mathrm{~m}$ (床上 $1.2 \mathrm{~m}$ ) のエリアを対象とし、その面内の $1.0 \mathrm{~m}$ グリッド上の点(図 4)におけ る $L_{p \mathrm{E}}$ を求め、それらのエネルギー平均值(平均音圧暴露レベル、以 下平均 $L_{p \mathrm{E}}$ )を求めた。その值の表示のしかたとしては、インパルス 音源のオクターブバンドあたりの音響エネルギーレベルを $100 \mathrm{~dB}$ としたときの各受音点における音圧暴露レベル $\left(L_{p \mathrm{E}}\right)$ を用いた。

過渡応答アニメーションは隣接教室への音波の伝搬における各建 築部位の寄与を把握しやすい一方で、定常状態の音圧レベルを知る
ことはできない。そこで、定常状態の音圧レベルを示すために音圧 暴露レベルの空間分布を用い、さらに検討条件間の差異を定量的に 比較するために受音側室内における平均音圧暴露レベルを求めた。

なお、本研究における数值解析ではインパルス音源による過渡応 答を計算しているので、音源の音響放射量については音響エネルギ ーレベル $\left(L_{J}\right)$ 、各受音点における音圧暴露については音響暴露レ心゙ ル $\left(L_{p \mathrm{E}}\right)$ を用いているが、これらは、バンドノイズなどの定常音源を 用いたときの音源の音響パワーレベル $\left(L_{W}\right)$ 、受音点における音圧レ ベル $\left(L_{p}\right)$ にそれぞれ対応している。特に記述のない限り、以下では $500 \mathrm{~Hz}$ を中心周波数とする 1 オクターブバンドにおける結果を表す ものとする。

\section{3 数值解析と実測との対応}

以上に述べた方法による数值解析の有効性を確認するために、実 在するオープンプラン教室をモデル化して解析した結果と実測結果 との比較を行った。検討の対象とした教室配置及び測定点の位置を 図 5 に示す。実測では、音源室内の床上 $1.5 \mathrm{~m}$ の点に無指向性音源 として 12 面体スピーカ(TS-12S)を設置し、ホワイトノイズを放射し た。受音には、無指向性マイクロホンを用い、床上 $1.2 \mathrm{~m}$ の点に設 置した。測定結果は、音源のパワーレベルを 1 オクターブバンドご

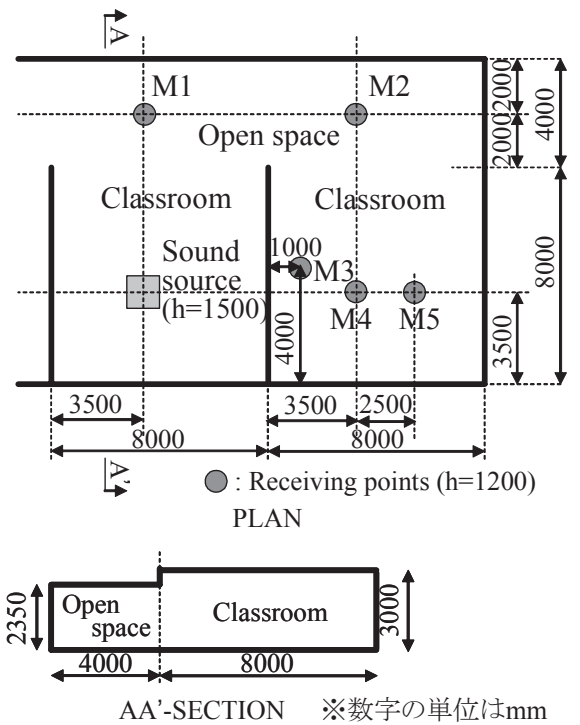

図 5 測定対象校の教室配置および測定点
表 1 仕上面の条件と想定した吸音率

\begin{tabular}{c|c|c}
\hline 建築部位 & 仕上材料 & 設定した吸音率 \\
\hline 天并 & 岩面吸音板 & 0.4 \\
\hline 壁 & 石膏ボード & 0.1 \\
\hline 床 & フローリング & 0.1 \\
\hline
\end{tabular}

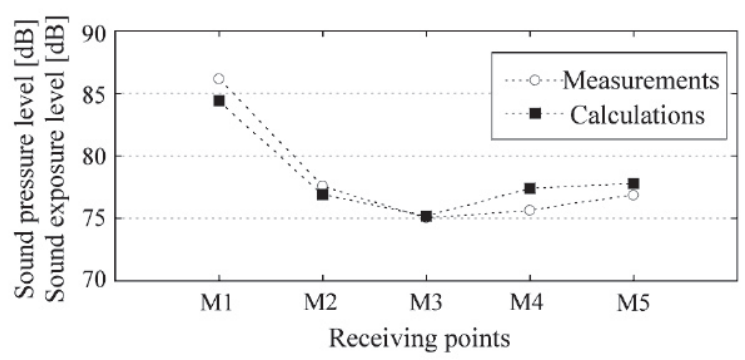

(500 Hzを中心周波数とする1オクターブバンド)

図 6 実測と解析結果の比較
(A)

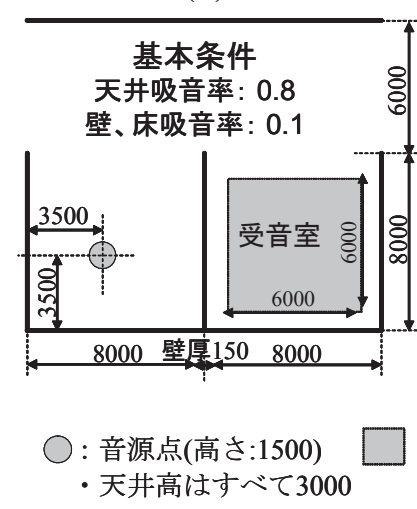

(B)

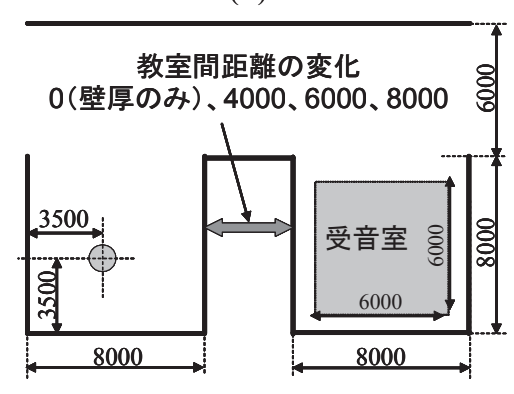

: 平均音圧暴露レベルを求めた範囲 ・各条件の境界面吸音率はすべて基
(C)

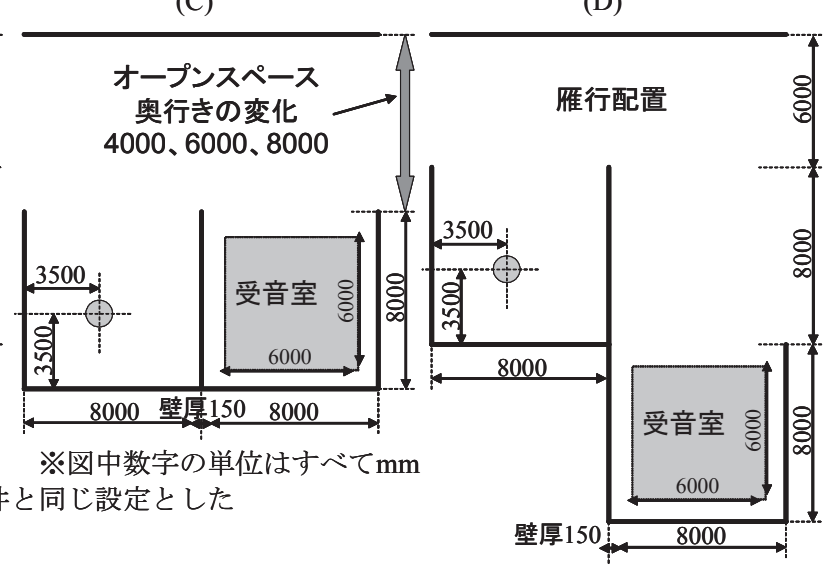

図 7 数值解析の検討条件(教室の平面配置) 


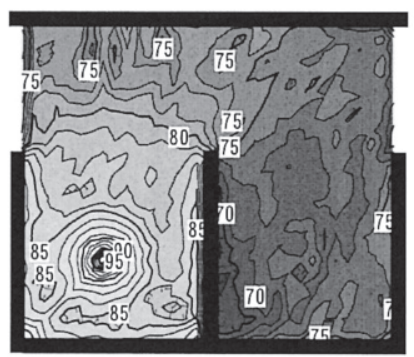

(A): 基本条件

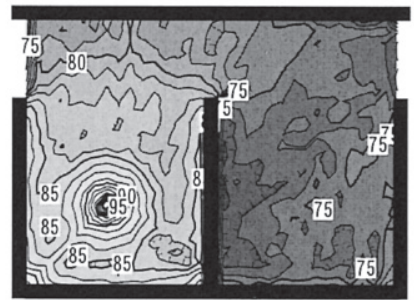

(C-1): オープンスース の奥行き $4 \mathrm{~m}$

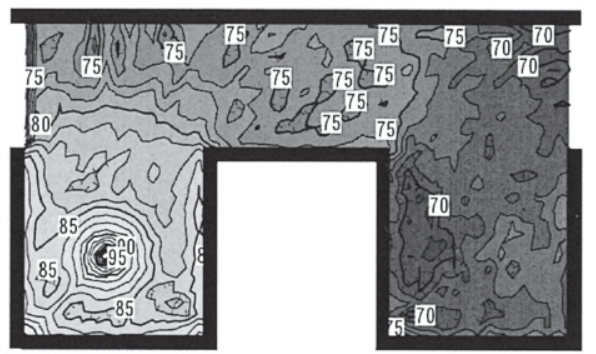

(B): 教室間距㑪 $8 \mathrm{~m}$

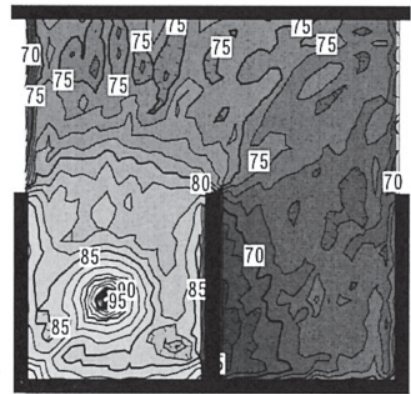

(C-2): オープンスペース

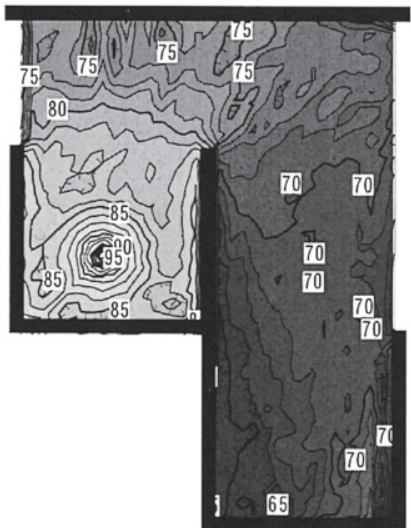

(D): 㭊行配置 (8 mずれ)

の奥行き $8 \mathrm{~m}$

図 8 音圧暴露レベル $\left(L_{p \mathrm{E}}\right)$ 分布図(高さ $\left.1.2 \mathrm{~m}\right)$ (教室の平面配置)

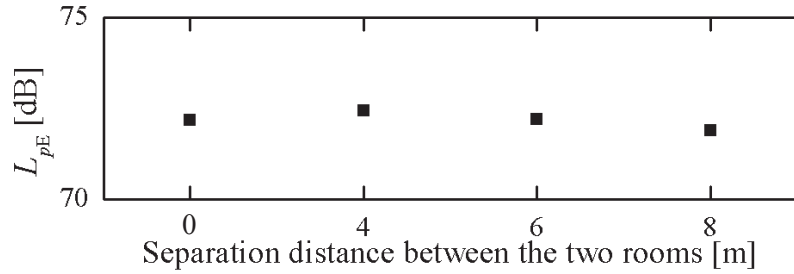

図 9 教室間の距離の差に関する平均 $L_{p \mathrm{E}}$ の結果

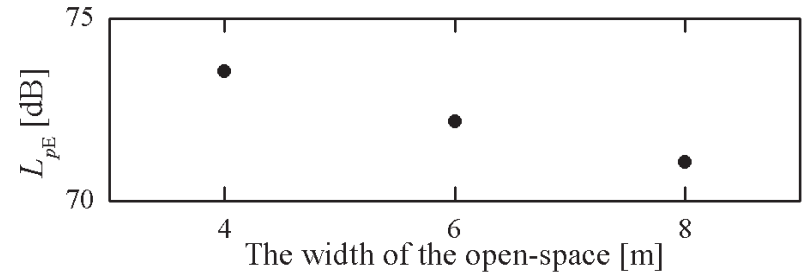

図 10 オープンスペースの幅の差に関する平均 $L_{p \mathrm{E}}$ の結果
とに $100 \mathrm{~dB}$ としたときの音圧レベル(以下 $L_{p}$ )に換算して表示した。 対象とした教室の室内仕上げの条件および数值解析で設定した各面 の吸音率を表 1 に示す。

各受音点における実測值 $L_{p}$ および計算値 $L_{p \mathrm{E}}$ を図 6 に示す。両者 は、すべての点でほぼ一致した結果となっている。したがって、本 数值解析法は、オープン教室配置の音響伝搬特性の把握、およびそ の低減方法を検討する上で有効であると言える。

\section{3. 教室間の音響伝搬の低減方法に関する検討}

図 3 に示寸数值解析の結果を見ると、OP 教室配置における隣接 教室間の音の伝搬では、 $36 \mathrm{~ms}$ 以降に見られる OS の壁面による反射 音、 $24 \mathrm{~ms}, 36 \mathrm{~ms}$ に見られる二つの教室を隔てる壁面の端部におけ る回折音という二つの成分が隣室への音波の伝搬に大きく寄与して いることがわかる。そこで、OP 教室配置における隣接 2 教室間の 音の伝搬を低減させる方法として、上記二つの成分の低減手法を含 めた以下の 5 項目について検討を行った。

1) 教室の平面配置の方法

2) 天井の吸音と形状変化

3) 回折音低減のための工夫

4) オープンスペース壁面の工夫

5) 家具設置による効果

この検討で対象とした教室配置のバリエーションを図 7 に示す。
そのうち、(A)は典型的な並列型 $\mathrm{OP}$ 教室で、これを基本として、(B) 二教室を離した場合、(C) OS の奥行きを広げた場合、および (D) 教 室を雁行配置とした場合の効果を調べた。なお、計算における境界 条件としては、天井の吸音率を 0.8 、壁・床の吸音率を 0.1 とした。 また音源は床上 $1.5 \mathrm{~m}$ に設定した。

\section{1 教室の平面配置}

\section{1 .1 教室間の距離}

隣接二教室を離すことによる効果を調べるために、図 7 の(A)を基 本条件 $(0 \mathrm{~m})$ として $(\mathrm{B})$ に示寸ように教室間の距離を $4 \mathrm{~m}, 6 \mathrm{~m}, 8 \mathrm{~m}$ と 段階的に大きくしたときの隣室への伝搬音の変化を調べた。その結 果として、教室間距離 $0 \mathrm{~m}$ と $8 \mathrm{~m}$ の場合の音圧暴露レベル分布を図 8(A) と (B)に比較して示す。また各条件における受音側室内の平均 $L_{p \mathrm{E}}$ を図 9 に示寸。これらの結果から、隣接教室間の距離を大きくし ても、伝搬音の低減効果は基本条件と比較して差が小さいことが分 かる。これは、OS 壁面における反射の影響がいずれの条件でもほ とんど変化がないためである。

\section{1 .2 オープンスペースの奥行き}

OS の幅の効果を調べるために、図 7(C)に示すように、OS の奥行 きを $4 \mathrm{~m}, 6 \mathrm{~m}$ (基本条件), $8 \mathrm{~m}$ の 3 段階に変化させて検討を行った。 その結果として、まず $L_{p \mathrm{E}}$ の分布の変化を図 8 の(A), (C-1), (C-2)に示 す。また受音側室内の平均 $L_{p \mathrm{E}}$ を比較して図 10 に示す。これらの結 果から、OS の奥行きを大きくすることによって、受音側室内への 
伝搬音を低減できることが確かめられた。

\subsection{3 雁行配置}

図 7(D)に示す雁行型の教室配置についても、同様の検討を行った。 まず $L_{p \mathrm{E}}$ の分布の計算結果として図 8 の(A) と(D)を比較すると、後者 の場合に受音側室内のレベルが低くなっている様子が見られ、両条 件における受音側室内の平均 $L_{p \mathrm{E}}$ の差は $3.8 \mathrm{~dB}$ となっている。この ことから、雁行配置は伝搬音の低減に効果的であると言える。

\section{2 天井の吸音と形状}

教室に限らず一般に天井の吸音処理は残響抑制および騒音伝搬の 低減の上で重要である。そこで、天井を吸音処理した場合、さらに 天井の高さ・形状を変化させた場合の隣接教室への伝搬音の低減効 果について、図 11 に示寸条件を設定して検討を行った。

\section{2 .1 天井仕上げの吸音率}

天井吸音の効果を確認寸るために、図 11 に示寸教室配置(図 7(A) の基本形と同じで天井高は $3 \mathrm{~m})$ において、天井の吸音率を 0.1 から 0.8 まで変化させて受音側室内の平均 $L_{p \mathrm{E}}$ を比較した。その結果を図 12 に示寸が、天井面の吸音率が高くなるにつれて受音室の平均 $L_{p \mathrm{E}}$ が減少する傾向が明らかで、吸音率が 0.1 の場合に比べて 0.6 以上 の条件では約 $7 \mathrm{~dB}$ の差が見られる。この結果から、天井の吸音処理 は教室間の音の伝搬を低減させるためにきわめて効果的であること が確認された。ただし、吸音率が 0.6 以上では平均 $L_{p \mathrm{E}}$ にほとんど差 がみられない。これは、伝搬音の音圧レベルには吸音率の対数が関 係するためと考えられる。この結果から、隣接教室間の音の伝搬を 低減するためには、天井面の吸音率が 0.6 以上となるような仕上げ とすることが有効であると言える。

\subsection{2 天井高}

平成 17 年の建築基準法改正によって教室の天井高の最低基準が 3 $\mathrm{m}$ から $2.1 \mathrm{~m}$ に引き下げられ、天井高について設計の自由度が広が った。そこで、天井高の違いによる伝搬音の変化について検討を行
つた。計算条件としては、図 11(F)に示す $(\mathrm{F}-1, \mathrm{~F}-2, \mathrm{~F}-3, \mathrm{~F}-4)$ の 4 種類 を設定した。その結果を図 13 に示すが、(F-1)と(F-2)を比較すると 両者の平均 $L_{p \mathrm{E}}$ の差は約 $2.1 \mathrm{~dB}$ であり、天井高を低くすることで伝 搬音が低減した。また、OS の天井高を低くした条件(F-3) と教室の 天井高を低くした条件(F-4)を比較すると、(F-4)の方が約 $0.7 \mathrm{~dB}$ 小 さくなっているが、その差はわずかである。

\subsection{3 天井形状}

木造校舎では、教室の天井を傾斜させている事例がよく見られる。 そこで、このような傾斜した天井をもつ OP 小学校をモデル化し、 図 11 の $(\mathrm{G})$ に示寸 4 条件を設定し、天井の吸音処理の効果も含めて 検討した。その結果を図 13 に示すが、天井を吸音処理した条件(G-2, G-4)を比較すると両者の平均 $L_{p \mathrm{E}}$ の差は $0.4 \mathrm{~dB}$ とわずかである。ま た、天井を吸音処理していない条件(G-1, G-3)の平均 $L_{p \mathrm{E}}$ を比較する と、(G-3)の場合に $1.2 \mathrm{~dB}$ 低くなっているが、その差はわずかであ る。この結果から、天井の傾斜の影響はそれほど大きくないと言え る。しかし、条件(G-1)と(G-2)、(G-3)と(G-4)の結果の差が示すとお り、天井の吸音処理の有無の差はきわめて大きい。

\section{3 回折音低減のためのエ夫}

つぎに、回折による隣接教室間の音の伝搬を低減するための工夫 として、図 14 に示すような $\mathrm{T}$ 字型と $\mathrm{Y}$ 字型の 2 種類の隔壁の形状 を設定し、その効果を検討した。

\subsection{1 $T$ 字型}

図 14 の $(\mathrm{H})$ に示すように隔壁を $\mathrm{T}$ 字型とし、袖壁の長さを 3 段階 に変化させた場合 $(\mathrm{H}-1, \mathrm{H}-2, \mathrm{H}-3)$ の伝搬音の違いを検討した。その結 果として、図 15 に受音室における平均 $L_{p \mathrm{E}}$ の計算結果を示すが、袖 壁が長いほど、伝搬音が若干低減する傾向がみられる。

\subsection{2 $Y$ 字型}

図 14(I)に示す三条件について、図 15 に平均 $L_{p \mathrm{E}}$ の結果を示すが、 $\mathrm{T}$ 字型と同様、壁面が長いほど伝搬音の低減量が増寸傾向がみられ

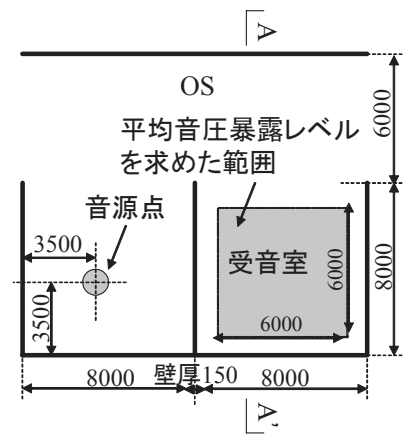

平面 (基本形状と同様)
(E): 天井吸音率 $0.1-0.8(0.1$ 間隔で変化) ·天井高: 3000

$(\mathrm{F})$ : 天井高の変化 ·天井吸音率: 0.8

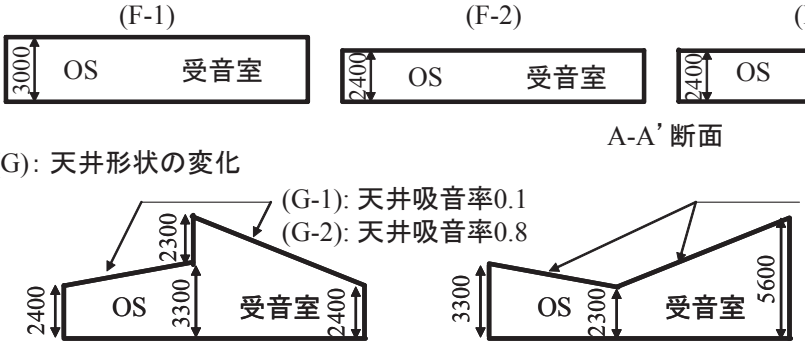

$\mathrm{A}-\mathrm{A}^{\prime}$ 断面 ※単位はすべてmm
(G-3): 天井吸音率 0.1 (G-4): 天井吸音率 0.8

図 11 天井の吸音と形状変化に関する検討条件

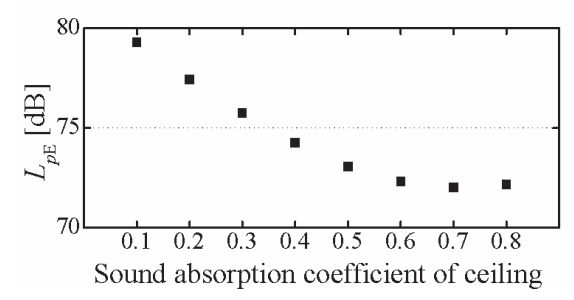

図 12 天井吸音率の差異の平均 $L_{p \mathrm{E}}$

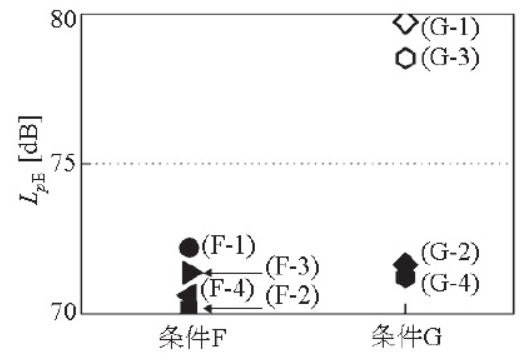

図 13 天井高および天井形状条件の平均 $L_{p \mathrm{E}}$ 
(H) $\mathrm{T}$ 字型

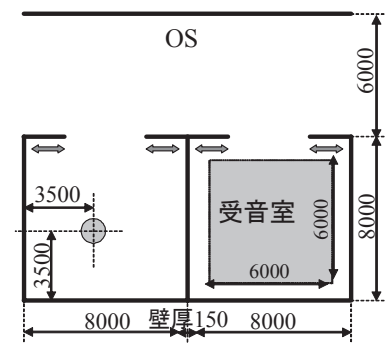

条件 $(\mathrm{H}-1): \Longleftrightarrow=500$

$(\mathrm{H}-2): \Longleftrightarrow=1000$

$(\mathrm{H}-3): \Longleftrightarrow=2000$
(I) Y字型

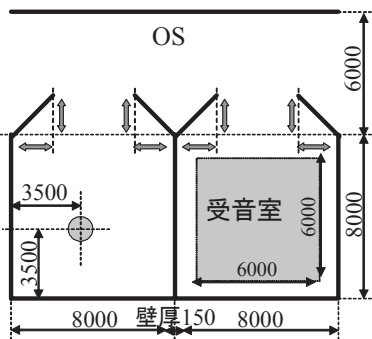

条件 (I-1): $\Longleftrightarrow=500$

(I-2): $\Longleftrightarrow=1000$

(I-3): $\Longleftrightarrow=2000$

○: 音源点 $\square$ : 平均音圧暴露レベルを求めた範囲 ※図中数字の単位はmm ・天井高はす心゙て 3000 ・各条件の境界面吸音率はす心゙て基本条件と同じ設定とした 図 14 検討条件(条件 H, I)

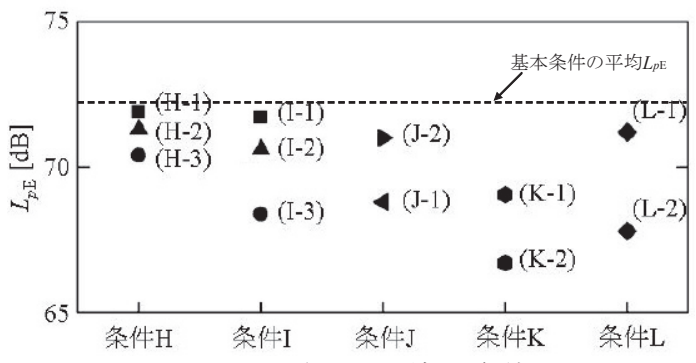

図 15 平均 $L_{p \mathrm{E}}$ の結果(条件 H-L)

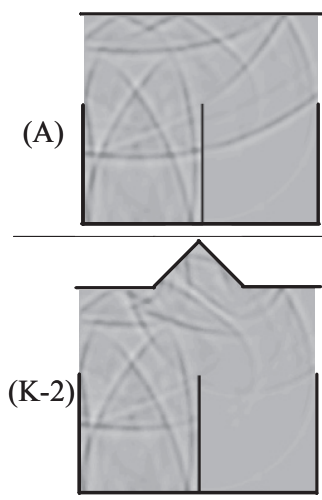

$60 \mathrm{~ms}$
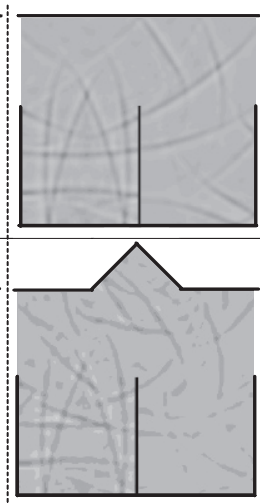

$80 \mathrm{~ms}$
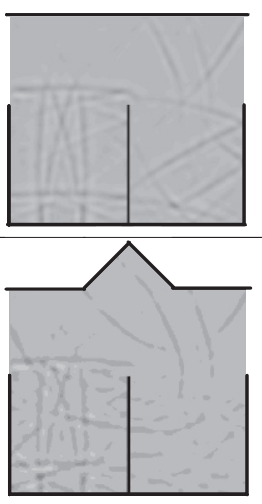

$100 \mathrm{~ms}$

図 18 基本条件(A), デン (K-2)の音響伝搬の様子 (高さ $1.2 \mathrm{~m}$ )

る。また、 $\mathrm{Y}$ 字型では、 $\mathrm{T}$ 字型の結果と比較して効果が大きい。こ の結果を音圧暴露レベル分布として図 16(H-3)および(I-3)に示すが、 この図からも効果の差が確認できる。

\section{4 オープンスペース壁面のエ夫}

OS 壁面における鏡面反射音が隣接教室間の音の伝搬に大きく寄 与しているため、この鏡面反射音を低減するため方法として、図 17 に示すように吸音処理および形状に変化をつけた場合の効果を検討 した。

\subsection{1 壁面吸音}

OS 空間の機能上、壁面全体を吸音処理することは難しい。そこ で、図 17 の(J-1), (J-2)に示すように吸音部位を壁面全体の半分に限 定した 2 条件を設定した。これらのうち(J-1)は二つの教室の境壁が 直面する部位を吸音面とした条件、(J-2)はその逆の条件である。こ
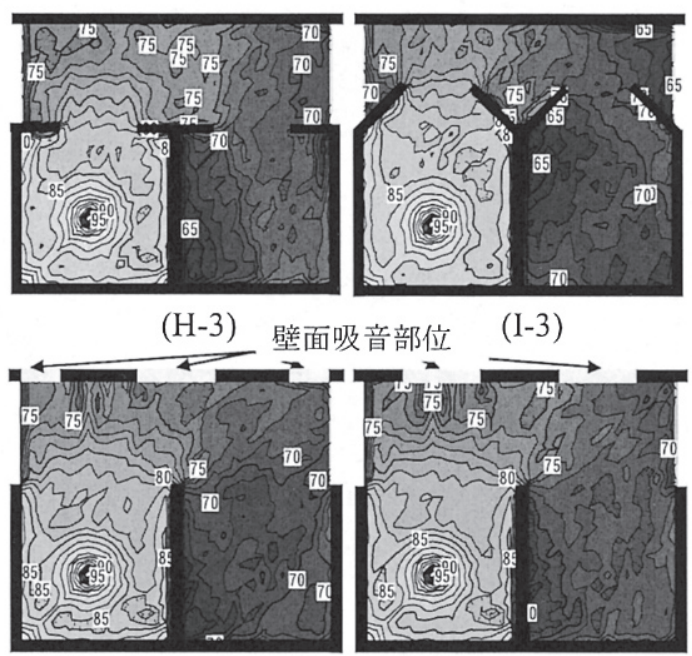

$(\mathrm{J}-1)$

$(\mathrm{J}-2)$

図 16 条件 $\mathrm{H}, \mathrm{I}, \mathrm{J}$ の $L_{p \mathrm{E}}$ 分布図 (高さ $1.2 \mathrm{~m}$ )

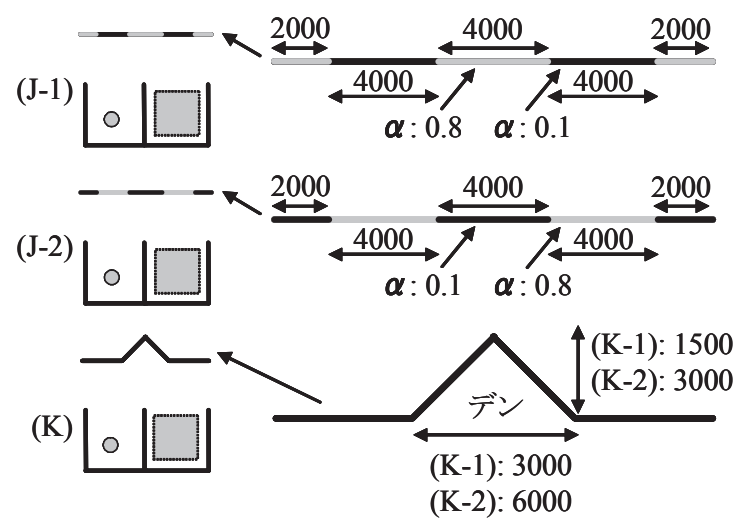

$\sqrt{\gg}$ OS壁面の傾斜: 外転び

(L-1): 傾斜角 5 度 (L-2): 傾斜角 10 度
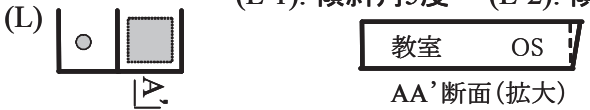

$\bigcirc$ : 音源点 $\square$ : 平均音圧暴露レベルを求めた範囲 - OS壁面以外の平面形状，天井高は基本条件に同じ - 壁面、床面 : $\alpha=0.1$, 天井面 : $\alpha=0.8$ ※図中数字の単位はmm

図 17 検討条件(条件 J, K, L)
れらの条件に対する計算結果を図 15,16 に示す。両条件の結果を比 較すると、(J-1)の方が (J-2) より伝搬音のレベルは $2.2 \mathrm{~dB}$ ほど低下 しており、この差は図 16 でも明らかである。これは、条件(J-1)では 鏡面反射が最も強くなる面が吸音面となっているためである。 3.4 .2 デン

児童の交流、休息スペースとして OS の壁に凹み（デン）を設け ることがある。このような壁面の変化の効果を調べるために、図 17 の(K-1), (K-2)に示す形態について検討を行った。その結果として、 受音側教室にける平均 $L_{p \mathrm{E}}$ を図 15 に示す。これらの結果を基本条件 (A)の場合と比較すると、条件(K-1)では $3.2 \mathrm{~dB}$ 、条件(K-2)では $5.5 \mathrm{~dB}$ の伝搬音の低減効果が見られる。この結果は、図 18 に見られるよう にデンの部分で音が音源側教室の方向に反射され、受音側教室に伝 搬しにくくなるためである。 


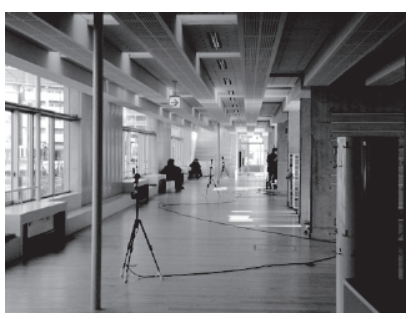

(M-1) : 家具なし

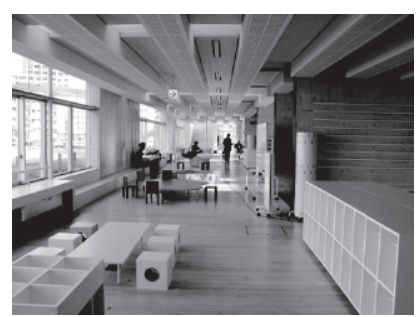

(M-2)：OS に備え付けの家具あり (M-3)：開校後（家具、荷物あり） 図 19 測定対象校の各種条件内観写真

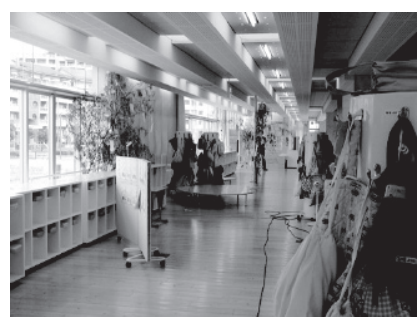

家具の概要

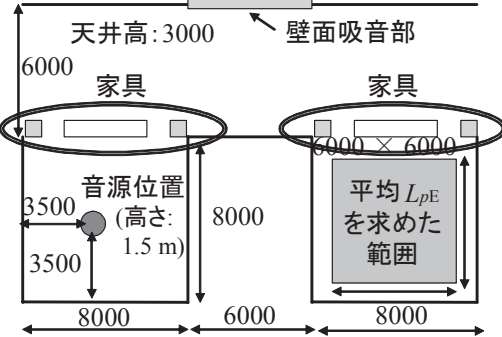

$\square: 500 \times 500$, 高さ 1500 , 側面4面吸音 (荷物を想定)

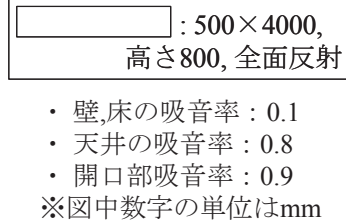

図 20 数值解析モデル概要

\subsubsection{OS 壁面の傾斜}

OS 壁面の反射の方向を変える方法として、その面を傾斜させる ことも考えられる。その場合、外転びにすることにより反射音が吸 音処理された天井で吸音される。この効果を調べるために、図 17 の(L)に示すように OS 壁面を 5 度および 10 度外転びとした条件に ついて検討を行った。平均 $L_{p \mathrm{E}}$ の計算結果を図 15 に示す。これを見 ると、基本条件に対して 5 度傾斜の条件(L-1)ではほとんど効果は認 められないが、10 度傾斜の条件(L-2)では、基本条件に対して $4.4 \mathrm{~dB}$ の低減効果が見られた。

\section{5 家具類の影響}

図 19 の (M-3)に見られるように、教室が実際に使われる状況では、 家具類や児童の荷物が OS に置かれる。そこで、これらが音の伝搬 にどの程度影響するかを知るために、実在の教室配置をモデル化し、 図 20 に示すように家具および児童の荷物（図中、丸で囲んだ部分） の有・無の 2 条件について解析を行った。家具および児童の荷物は、 図 19(M-2)の右側に写っているランドセル入れ、(M-3)の右側に写っ ている荷物をそれぞれ直方体としてモデル化し、吸音率は家具を 0.1 、 荷物を 0.8 と設定した。その結果、受音側教室内の平均 $L_{p \mathrm{E}}$ は家具類 なしの条件で $67.1 \mathrm{~dB}$ 、家具類ありの条件で $61.7 \mathrm{~dB}$ となっており、 家具類を設置することによって $5.6 \mathrm{~dB}$ の低減効果が認められた。

上記の数值解析の結果を確認するため、モデル化の対象とした新 築小学校において、開校前後で家具類の設置の状況が異なる 3 条件 (M-1：教室・OS ともに家具類なし、M-2：OS のみに備え付けの家 具あり、M-3：使用過程で児童の荷物などもある状態）について、 2.3 と同様の方法で実測を行った。測定時の OS の状況を図 19 に、 教室配置と測定点位置を図 21 に、測定結果を図 22 に示す。図中に 示す受音側教室内の平均音圧レベル $L_{p}$ の值は、定常音源の各オクタ ーブバンドの音響パワーレベルを $100 \mathrm{~dB}$ としたときのレベルで表 示した。測定結果を図 22 に示寸が、この結果を見ると、家具や児童 の荷物が増えるほど、隣室への伝搬音が低減する傾向が明らかに認
天井仕上: $\mathrm{GW}$, 有孔石膏ボード(GW裏打)

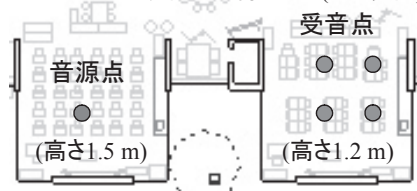

図 21 測定対象校の概要

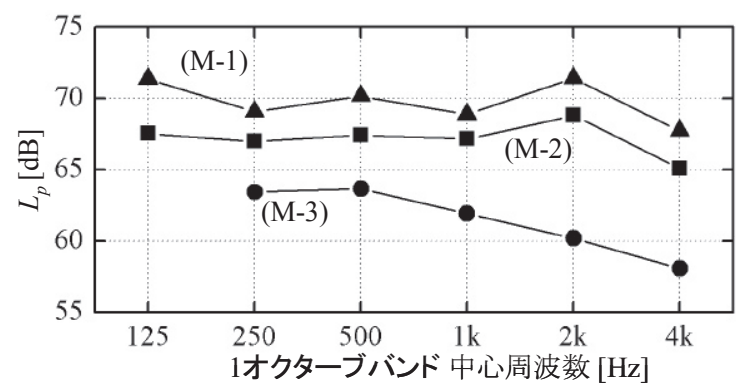

図 22 家具の配置の差異に関する実測結果

められる。500 Hzのオクターブバンドの結果を見ると、家具類の設 置による伝搬音の低減効果は上述の数值計算の結果とほぼ同様とな っている。

\section{4. まとめ}

オープンプラン教室では複数の教室が空間的に連続しているので 音の伝搬は避けられず、これを緩和するための建築的工夫が必要で ある。本報では、そのための基礎資料を得るために FDTD 法による 数值解析および実測調査によって検討した。その結果を取りまとめ ると以下のとおりである。

(1) 教室の配置

OP 教室が並列に配置されている場合、教室間の距離を大きくす るだけでは伝搬音の低減効果はあまり期待できない。これは、OS 壁面で鏡面反射される音の寄与が大きいためである。

教室の雁行配置は、通常の並列配置に比べて音の伝搬は小さくな る。ただし、そのためには OS の面積が大きくなる。

(2) OS の奥行き

隣接教室間の音の伝搬を緩和するためには、OS の奥行きを大き くすることが効果的である。

(3) 天井面の吸音処理

天井面を吸音処理することは、室内の残響を抑制するだけでなく、 教室間の音の伝搬の低減にもきわめて効果的である。そのためには、 仕上げ面の吸音率としては、中音域で 0.6 以上とすることが望まし い。

(4) 天井の高さ

天井高の違いによる教室間の音の伝搬の変化に関して、高さ $3 \mathrm{~m}$ と $2.4 \mathrm{~m}$ の条件の違いについて検討した結果、天井高が低いほうが 教室の音の伝搬が緩和されることがわかった。

(5) 教室間の隔壁の形状

隣接教室間の隔壁の先端断面を $\mathrm{T}$ 字型および $\mathrm{Y}$ 字型にすることに 
より、回折伝搬を低減することができる。その程度は、 $\mathrm{T}$ 字型に比 べて Y 字型の方が大きい。

(6) OS 壁面の処理

OS の壁面は隣接教室間の音の伝搬に対する寄与が大きいので、 この部分を吸音処理する、あるいはデンなどを設けて形状を変化さ せることによって、かなりの程度の伝搬音の低減が期待できる。

(7) 家具類の効果

教室および OS に置かれる家具類は、教室間の音の伝搬に対する 低減要素となる。さらに、吸音性の高い体操着などの児童の荷物の 設置場所を工夫することにより、音の伝搬を低減する要素として利 用することができる。

\section{謝辞}

本研究を進めるにあたり、学校建築の実設計および運用面における 問題点についてご議論いただいた CAt の小嶋一浩氏、赤松佳珠子氏、 光本直人氏、大鹿智哉氏に謝意を表します。また、実測調査にご協 力いただいた小学校関係者各位に感謝いたします。

\section{参考文献}

1) 長倉康彦：「開かれた学校」の計画，彰国社，1993

2) 上野淳 : 未来の学校建築 教育改革をささえる空間づくり, 岩波書店, 1999

3) 青木亜美, 上野佳奈子, 橘秀樹 : 音環境に着目したオープンプラン小学 校の実態調查に基づく研究, 日本建築学会計画系論文集 No.562, pp. $1-8, \quad 2002.12$
4) 橋本都子, 倉斗綾子, 宗方淳, 丹沢広行, 上野淳 : 学校教室の印象およ び環境評価の実態一首都圈の小・中・高等学校の児童・生徒を対象とし たアンケート調查結果, 日本建築学会大会学術講演梗概集 E-1, pp $1121-1122, \quad 2006.9$

5) 井上勝夫, 冨田隆太 : オープンプラン型小学校における音環境の実態と 教師・児童の意識, 日本建築学会環境系論文集 No.576, pp. 1-8, 2004.2

6) 福地智子, 上野佳奈子, 井上諭, 内田匡哉, 佐久間哲哉, 土屋裕造, 矢 入幹記, 渡辺充敏 : 日本建築学会環境工学委員会研究会「学校施設の音 環境保全規準」資料, 2004

7) 井上勝夫, 橋本修, 冨田隆太, 福山忠雄 : オープン型小学校における音 環境の実態と評価, 日本音響学会建築音響研究会資料 AA2001-35, 2001

8）福山忠雄, 土屋裕造, 井上勝夫, 山崎芳男 : 学校教室の音環境の実態と 模型実験による教室間遮音の検討, 日本音響学会建築音響研究会資料 AA2001-36, 2001

9) 中島章博, 上野佳奈子, 坂本慎一, 橘秀樹 : 新設小学校の音響性能に関 するケーススタディ，日本音響学会建築音響研究会資料 AA2006-29, 2006

10) Shinichi Sakamoto, Yasuhiro Tokita and Hideki Tachibana : Calculation of impulse responses of rooms by using of the finite difference method, Proc. of ASA and ASJ Third Joint Meeting, pp. 1307-1310, 1996

11）中島章博, 上野佳奈子, 坂本慎一, 横田考俊, 橘秀樹 : FDTD 解析に基 づくオープンプラン型教室の音響設計, 日本音響学会建築音響研究会資 料 AA2005-36, 2005

12) Akihiro Nakajima, Kanako Ueno, Takatoshi Yokota, Shinichi Sakamoto and Hideki Tachibana : Study on sound transmission between open-type classrooms by numerical analysis, Acoustical Science and Technology Vol. 26 No. 6, pp. 537-539, 2005

13) Akihiro Nakajima, Kanako Ueno, Shinichi Sakamoto, Hideki Tachibana : Numerical analysis of sound propagation between open-type classrooms, Inter-noise 2006 No.775, 2006

（2007年 9 月10日原稿受理，2008年 1 月15日採用決定） 